\title{
MODERN ROBBERS: SPECIAL INTEREST GROUPS AND BRAKING THE ECONOMIC GROWTH ${ }^{1}$
}

\author{
Konstantin Yanovskiy \\ Head of Institutional Development Department \\ Gaidar Institute for Economic Policy Moscow, Russia \\ Cherney, D.
}

Russian Presidential Academy of National Economy and Public Administration research fellow Varnadskogo Avenue,82 Moscow, Volgograd region 119571 Russia

Shadrin A.

Director of the Department of Innovative Development of the Ministry of Economic Development of the Russian Federation.

Small well-motivated groups, including state officials, public and community activists, politicians etc proved their capacity to impose burden on economy. The power to do so in modern Market Democracies could be reached without "unsheathing the sword". Old fashioned redistribution experts - roving bandits are crowded out by modern ones. The most common way is to use the whole of the state apparatus as a "sword," and to resort for cover to care for the needy and protection of the vulnerable, the ill-informed, the weak, the sick, or the "unwise" economic agents from all kinds of possible dangers.

The longer list of the categories of persons in need of protection because of their "weakness," "underprivileged statute in the past" etc, the easier it becomes to justify regulatory interference, the growth of the state apparatus, the increase in state insurance programming, and other budgetary expenses.

Classical liberal epoch's legislator presumed the economic agent is reasonable, rational and responsible. This assumption had been gradually substituting for the last century, by the implicit assumption of citizen's' limited capacity.

The mechanism of the impact upon economic growth achieved by means of special interests groups' expansion has been described by M. Olson. "Protection" takes place by means of market entry barriers placed in the way of agents or by means of various controls and regulations.

\footnotetext{
${ }^{1}$ The paper presented is the 3rd chapter of the book "How the Import of Modern Western Institutions Suppresses Economic Growth: 1990-ties East-West and West-East Transition" (in Russian original: "Institucionalnye ogranichenia sovremenogo ekonomicheskogo rosta" - Institutional Constraints on Modern Economic Growth - "Delo" Publishing House Moscow, 2011). The book is in translation currently. See the book structure and the chapters' content short description.
} 
One who imposes heavy Regulatory burden in the emerging markets, in transitional economies with weak property protection makes running fair business almost unaffordable.

Keywords: special interest groups, personal capacity assumptions, excessive regulation, regulations' reproduction

JEL codes: D73, K20, N14, O43

Soon enough will all my friends Make it into higher-ups. And when that comes true, then I Will, I think, do well.

Visit Bella's office I Will, and say, "Hi, Bella! Bit of problem here we have, help me solve it fast." "This is nothing!" She will say, "Don't call this a problem!" And, of course, right then I'll start living simply well.

B. Okudzhava

Government "help" to business is just as disastrous as government persecution... the only way a government can be of service to national prosperity is by keeping its hands

off.

Ayn Rand

The wealth of a particular individual far from always accrues thanks to the individual's hard work and talents which bring about the emergence of a financially stable demand for his or her goods and services on the free market. A strong and cruel type unburdened by restrictions (of either the legal or the moral kind) can simply use force to take whatever he sets his heart upon. In Chapter 1 we noted that a key element in successful conducting of business affairs is the immunity of the life, health, freedom, and security of property owners. All this is, in turn, ensured by a favorable business climate. In Chapter 4 we will consider in greater detail the most dangerous (by force of the special features of modern post-industrial society) technologies of "selection" of the values listed above.

The "roving bandit" of the classical type does not survive in a state whose government is restricted by law and capable of fulfilling such state functions as maintaining law and order. Exceptions to this rule surface in situations when a "roving bandit" is in a position to take over the state. Even if law enforcement 
functions as such are difficult for the state to master (for instance, California of the Gold Rush period), opportunities for coerced redistribution of property are rather limited.

Results of psychological studies conducted by D. Kahneman et al. to assess human relating to risk and indeterminacy indicate "a disproportionately greater" tendency among most market agents to invest in defending their property. ${ }^{2}$

This means that a member of the minority tending in favor of risk faces a choice: either to use his or her penchants and venturesome spirit in order to satisfy the needs of those all around, or to attempt to take away the property of others if they should resist this; all this while market agents' resistance will be thoroughly effective. This is conditioned by the institutional options available to free individuals in a free country (the ones who can bring to bear the power of law enforcement agencies, hire bodyguards, acquire weapons, and fortify their homes). Most individuals tend to invest funds in defending themselves, all while had they invested the same funds in alternative projects, they could have significantly increased the expected value of their income and the volume of their property in the next period.

The "stationary bandit" (if strong enough) is not likely to tolerate types who undermine his basis for exacting levies. ${ }^{3}$ Yet applying force for purposes of enrichment by means of redistribution is something one can do without so much as drawing one's sword from its scabbard. The most widespread method is using the state apparatus as a "sword," with cover up for the process provided by care for the needy, defending the vulnerable, the little informed, the weak, the ill, the underdeveloped and irresponsible economic agents (one's fellow citizens) from threats of all kinds.

A particularly convincing argument for state interference is the need to protect women and children (see Chapter 11). Quite successful are projects targeting the protection of animals, national minorities, "unwise" consumers, preservation of nature as a whole, as well as "global warming," "technogenic catastrophes," and the like. ${ }^{4}$

\footnotetext{
${ }^{2}$ Kahneman, Slovic, Tversky, 1982.

${ }^{3}$ For example, execution by order of the Sultan Hetman Yuriy Bogdanovich Khmelnitzky in 1685. See http://partners.academic.ru/dic.nsf/enc biography .

${ }^{4}$ The authors acknowledge the problem of information asymmetry and the existence of external factors in many situations. The issue involves not problems per se, but rather the fact that problems are convenient to take advantage of for special interest groups so as to extend the ability of friendly officials to take authorized action or so as to obtain rental payments. Practice shows that, on the contrary, problem solutions groped for without state interference or in the course of normal court proceedings can turn out to be quite effective (see the collection of court cases cited in Coase, 1993;
} 
A productive field for the "new robbers" has proven any project bound up with information asymmetry and the likelihood of manipulation, considering that poorly argued for spending is easy to hide behind global problems.

The category of citizens defined as extremely poor and in need of protection often included the rather rich and powerful, such as those entrepreneurs who were friendly with the authorities. Bankers were frequently to be found among these last $(\mathrm{H}$. De Soto 2008). Waving the banner of struggling for market competition against monopolies, the state began to provide aid for unlucky entrepreneurs as far back as the late 1800s (Armentano 2006).

The larger the number of persons in need of protection due to "being unwise," the easier it becomes to argue for state interference, growth of state apparatus, increasing state insurance programs, and other budgetary expenditures.

The notion of the citizen as a person incapable of concerted action and needing various caveats (concerning the undesirability of using chlorine-containing cleaning substances for food, of pouring hot coffee on oneself, of using microwave ovens for drying household pets, and the like), brings the human being down to the level of an animal, thus opening an enormous field of action for "defenders," such as officials and lawyers. But these last are busy not with advancing the project of supplying the market with goods and services to satisfy consumer needs, but with de facto obtaining payment for allowing passage over the administrative barrier. In this capacity they, along with the core of interest groups - the officials and politicians who first provided for the establishment and legitimation of the barrier - are in essence no different from the medieval feudal lords who relied on their right of force to exact payment for permitting passage through their territory.

M. Olson was of the opinion that parasitic special interest groups bear the brunt of responsibility for slowing down economic growth in nearly all industrialized countries (Olson 1982). As we have already noted, the absence of guarantees of personal security and immunity of the individual person pose much more serious of an obstacle to long-term economic development than activities undertaken by parasitic groups. Even so, the capacity of these groups for lowering growth rates leaves no doubt. We should also not forget some of the external political effects of steps taken by these groups (see Chapter 13).

and the widespread market practice of paid services in testing used vehicles at the time of sale, and the like). 
In 2000-2001, the authors of the new Russian licensing law put forth the following condition for state interference in defense of the consumer by means of issuing licenses for certain types of activities:

The existence of an obvious and direct threat to the consumer as a result of the possibility of dishonest actions performed by the producer or the seller of the goods or services in the absence of alternative systems of verification or opportunities for providing the quality and security standard required.

As long as the Law was being worked on and ratified and while the multi-lateral discussions were in progress, the principle here introduced was universally acknowledged. Nonetheless, in the end, the Law $^{5}$ failed to protect business from semiarbitrary procedures as a part of the licensing process.

\section{Methodology for Studying the Obstacles Standing in the Way of Business and Failures to Create a Favorable Investment Climate: Some Worthwhile Approaches}

Among the leading world centers studying business climate and its determining factors, organizations connected with the World Bank are particularly deserving of attention.

Many of their studies are simple in methodology, yet they may prove of value as collected volumes containing examples and descriptions of specific situations. These studies, constructed with a view to grounding "banal truths" (about the harm caused by confiscating property, about the usefulness of protecting property and due delimitation of rights, about the need carefully to weigh every regulatory decision) could be the best textbook for decision makers. Yet these last, due to their natural

\footnotetext{
${ }^{5}$ See the Federal Law of August 8, 2001, №128-F3 “On Licensing Certain Types of Activity." Other criteria are also possible (see, for instance, Tambovtzev 2004). However, it appears that limited achievements are in this case due not to theoretical under-development, but to the regular pressure exerted by interested groups in the absence of an appropriate counterweight.
} 
desire to maximize their own gain rather than the good of society, avoid reading such studies, which are both popular as well as quite profound (World Bank 2005).

Recent years have seen the comparative studies Project "Doing Business" get under way. ${ }^{6}$ As part of the project, researchers collect data for typical business expenses, basing their approach largely on the work done in Peru by Hernando De Soto, ${ }^{7}$ which has become classic since. At present, they are collecting comparable data as per the following categories:

costs of company registration (number of procedures, time periods, and expenses);

costs of obtaining licenses and permissions;

costs of registration of property;

labor relations (indirect expenditures for labor force as a percentage of per time unit wages; costs of dismissal and package of indices which, using experts' views, evaluate complexity of hiring and dismissal);

payment of taxes (number of payments); total per annum time expended on payment of taxes (in hours); "comprehensive tax" (as a percentage of gross profit);

international trade (number of documents pertaining to import-export, time expended, and operational costs);

procedures of compulsory execution of contract (number, time periods); and company dissolution (time periods, costs).

Something that exerts influence of an indirect, but extremely sensitive kind on business climate is the quality of state authority institutions. The attempt is made to evaluate this as part of the "Worldwide Governance Indicators" (WGI) project being conducted by the World Bank.

Evaluated as part of the readings were: political stability, absence of violence, quality of regulatory procedure, authority (superiority) of the law, and measures taken in the struggle against corruption. The evaluation was arrived at with the aid of both expert conclusions (by government and independent experts) and surveys. The project

\footnotetext{
${ }^{6}$ See: http://www.doingbusiness.org/; in particular, the data for 2009 at: http://www.doingbusiness.org/documents/Simulator_English_2009.xls; publications beginning in 2003.

${ }^{7}$ Hernando De Soto, The Other Path: The Invisible Revolution in the Third World (Harper Collins, 1989) and The Other Path: The Economic Answer to Terrorism (Basic Books, 2002).
} 
uses data collected in a wide variety of research centers, from press associations (freedom of speech index) to Heritage Foundation ${ }^{8}$ (Economic Freedom Index).

The most interest-provoking have proven to be the data collected in entrepreneurs' and household surveys conducted in all countries. In particular, questions related to evaluating the authority of the law focused on:

Do you trust the police?

Do you trust the court system?

Have you ever been a victim of crime?

The index thus arrived at, consisting of 6 evaluations based on a five-point system (ranging from -2.5 to +2.5 ) thus aggregates a multitude of parameters. It is one of the most ambitious and integrated of its kind.

Russian Federation indicators improved considerably during the 1996-2006 period, but remained negative on the "political stability" and "quality of state management" counts. Somewhat better - as per the point of view of World Bank experts - are Russia's "measures taken in the struggle against corruption" (meaning not corruption per se, but the measures officially taken in the struggle against it).

Worse than previous are indicators measuring the extent of "transparence and accountability of governing agencies," "quality of regulative procedure," and "authority of the law."

The International Property Rights Index (IPRI) is developed and implemented by the Fraser Institute in Canada and its partners throughout the world. The 2008 rating covers 115 countries.

Developers tried to cover all key elements of defending property rights. With this end in view, they consider indicators related to a number of areas: legal and political environment, index of defense of property rights over tangible belongings (objects of physical possession), index of intellectual property defense, and gender equality.

$96 \%$ of the total gross domestic product (GDP) of the world's countries account for countries making up part of the sample (115). Each country is evaluated according to a ten-point scale (from 1 to 10$)$. Russia's integrated score is 4 points $\left(92^{\text {nd }}\right.$ among 115 countries). As per the integrated indicator, Russia is behind not only the developed European and North American countries, but also new EC members. Her rating neighbors are Uganda and Zambia (ahead) and Ecuador and Nepal (behind).

\footnotetext{
${ }^{8}$ Heritage Foundation Economic Freedom Index in the US.
} 
Albeit behind are also Armenia, Azerbaijan, and Moldova (Uzbekistan, Tajikistan, and Turkmenia do not participate in the rating).

Emerging with a score of 3.2 points for the "Legal and Political Environment" count, Russia takes $104^{\text {th }}$ place out of 115 (Zambia - for instance - is $71^{\text {st }}$ ). This index takes such factors into consideration as independence of courts and the trust put in them, political stability and corruption (as per World Bank data and the data of the World Economic Forum in Davos).

Russia's place in the rating results of the indicator showing "Defense of Physical Property Rights" (PPR) is almost the same as in the integrated rating: $93^{\text {rd }}$ out of 115.

Russia's level of protection of intellectual property (Intellectual Property Rights - IPR) looks somewhat better: Russia ranks $85^{\text {th }}$. The IPR indicator evaluates the degree to which rights to intellectual property - copyright, patents, and commercial trademarks - are protected from "pirate" use. But such a ranking of Russia is absolutely unacceptable considering her well-grounded claims about taking part in catching up with the countries technologically in the lead.

The general problem of studies based on expert rating evaluations of quality of institutions is this: different problems are evaluated in different ways.

\section{IRIS Surveys of Entrepreneurs about Trust Put in the Court System}

During the 1990s, T. Frye and researchers at the IRIS Center at the University of Maryland, led by M. Olson, conducted a number of surveys of entrepreneurs in Russia and Romania so as to determine their attitudes toward the court system. The surveys focused on arbitration courts; the problems uncovered on the basis of the survey results could be used in the reform and development process of the appropriate court institutions.

Surveys provide not only quantity evaluations, but also qualitative results (focus groups can emerge based on survey outcomes, as well as individual interviews which make it possible to evaluate the problem in greater depth).

At the same time, opportunities for making wide use of surveys are limited. Among the shortcomings of this particular research tool are costliness and the difficulty of obtaining mutually comparable results which could be used during the time while reforms are being introduced. 


\section{Special Interest Groups in Russia: Historical Roots, Present Condition and Perspectives}

The advent of the 1990s was marked by the elimination of a series of barriers which had been rather bothersome for private initiative; this provided the minimal conditions required for the existence of legal entrepreneurship. The disappearance of control over prices, Decree Concerning Freedom of Trade, sweeping privatization, liberalization of foreign economic activity, partial conversion of the ruble all led to the emergence of entrepreneurship as a prominent public phenomenon and social group with interests of its own. At the same time, for a long time it remained the case that investments in governmental decision making became the most profitable, ${ }^{9}$ something that enormously distorted the incentives for market participants, especially the largest among them who had the ability to obtain decisions most profitable for themselves and their business partners.

The absence of guarantees for basic rights, inadequate clarification of property rights definitions (due primarily to the authorities' involvement in property management and commercial activity), political indeterminacy up through late 1999 all lead to that the realization of the least long-term project raised entrepreneurs' demand for individual guarantees by the authorities and lowered the demand for universal lawful order. State management under such conditions becomes a species of apparatus for appropriating administrative revenue. As of the early 1990s, this revenue required formalized documentation and "legal" shape due to competition among the various power centers.

The exaggerated role played by the authorities in decision making concerning investment, over-the-board redistribution of property, absence of either large concentrations of capital at home or sizable quantities of foreign investors, along with a series of other reasons led to the intensification of the position assumed by those entrepreneurs who had "special" relationships with the authorities, or, as some assessments would have it, to the "coupling of property and authority."

Political instability was conditioned by the might of political coalitions and special interest groups connected with them, who focused either on restoring the state

\footnotetext{
${ }^{9}$ Mau, Boreskova, Novikov, et al. 1999.
} 
regulation system of the Soviet type, or on preserving the existing relations between authority in power and business.

One of the consequences of political instability became frequent replacement of enterprises enjoying individual privileges (Kontorovich 2000). All while change of government in such cases means drastically weakening the positions of some entrepreneurs and equally drastically strengthening the positions of others.

Most likely, deformation of incentives and interests was inevitable. The new state of affairs, which led to stronger authorities at the expense of business, created new problems for business, but at the same time also made the incentives "more wholesome." The loss of the sense of universal permissibility curbed only by the threat of physical destruction at the hands of competitors, and the new fear of the increasingly stronger repressive authorities gradually raise the demand for lawful order on the part of large businesses. ${ }^{10}$ Small and medium-sized businesses, unable to negotiate with the authorities with a view to anything at all reminiscent of the long term, voice demands of this kind even earlier (Klyamkin, Timofeev 2000; Frye 2002).

The first - and, thus far, the only - outcome of significance of the reforms in state management which were introduced by the administration and the government of the new President (the "Economy De-bureaucratization Program") has been the ratification of a package consisting of three laws:

The Law "Concerning Enterprise Registration" introduced the principle of a single "one-stop shop" at the time of registration, thus diminishing registration costs considerably.

The Law "Concerning Licensing Particular Types of Activity" (new version) cuts down the number of licensed types of activity.

The Law "Concerning the Defense of Legal Persons and Individual Entrepreneurs When State Control (Supervision) Is Conducted" introduced the formalization of certain types of control.

These were signed into law by the President of the Russian Federation on August 8, 2001. Later, in 2007-08, they were corrected in accord with implementation experience. At the same time, many of the particularly freely interpreted clauses

\footnotetext{
${ }^{10}$ For instance, see the proceedings of the round table discussion devoted to "Business and the Authorities" held in January 2001 at the National Research University - Higher School of Economics in Moscow.
} 
which had lessened pressure exerted upon business were eliminated from legislation defining the authority of law enforcement agencies.

According to the interpretation offered by Professor A. A. Auzan (leader of the "Social Contract" Foundation and Confederation of Societies for the Defense of Consumer Rights), development of the system of excess regulation in its contemporary guise has to do with the reaction by part of the state apparatus to the explosive growth of the market beginning on January 2, 1992. ${ }^{11}$ Suffusion of the market with great quantities of different products which had been inaccessible to the consumer earlier, coupled with total absence, on the part of this last, of knowledge or habits of orienting oneself in this myriad goods spawned the natural drive urgently to take measures which would lessen the problem of information asymmetry. Such asymmetry is typical for the beginning of reforms not only of the classic experienceand trust-based goods and services markets (medicine, technically complex goods), but also for primary food-related goods markets, as well.

The problem of consumer adaptation was a very real one in early 1992. But only one state decision has had anything to do with defending consumer rights since that time: ratification of the Russian Federation Law dated February 7, 1992, № 2300-1 "Concerning Consumer Rights," which drastically cut the cost of fighting on behalf of consumer rights, including defense in court. The new institution stimulated both commercial activity of private lawyers, and the creation of various specialized noncommercial organizations. Almost all the other measures enacted by the authorities had an essentially different aim.

In light of this, a different explanation appears well-grounded for the phenomenon of reproduction of excessive regulation and the origins of this problem.

\section{Deregulations' Attempts in the History of Russian Reforms}

The first laws package concerning regulatory reforms ${ }^{12}$ made an overall favorable impression on business. However, many people had expected more, and with good reason: only the Law "Concerning State Registration of Legal Persons"

\footnotetext{
${ }^{11}$ On April 5, 2001, at the Scientific Council of the Institute of Transition Period Economics (IET, Gaidar Institute for Economic Policy), devoted to the problem of the de-regulating of Russia's economy. See: www.iet.ru.

${ }_{12}$ This refers to the Federal Laws dated August 8, 2001,№ 128-F3 "Concerning Licensing Certain Types of Activity"; №129-F3 "Concerning State Registration of Legal Persons”; and № 134-F3 "Concerning the Defense of Rights of Legal Persons and Individual Entrepreneurs during State Control Checks (Supervision)."
} 
passed the Russian Federation Government and State Duma revision without substantial defects.

The new version of the Law "Concerning Licensing Certain Types of Activity" did not manage to meet the essential challenges set before it. Radically reducing the number of licensed types of activity - bringing them down to a few dozen types satisfying understandable criteria ${ }^{13}$ - proved impossible. The list continued to number more than 110 types of activity. It had also been assumed that the new version would rule out references to other laws and make the licensing control procedure universal. This did not happen: an entire series (more than 15) of licensed types of activity remained undocumented (including control of electronic mass media). Some of the types of activity subject to licensing are ill-defined (operation of production plants for explosives; operation of production plants for inflammables; operation of production plants posing a chemical threat), a fact which makes it possible by means of sublegal steps to extend licensing to dozens and hundreds of new types of activity.

Certain types of activity included in the list are extremely difficult to keep track of, thus encouraging misuse by law enforcement agencies ("passenger transportation by means of light automobile vehicles undertaken as a commercial enterprise").

Similar problems are also typical of the Law "Concerning the Rights of Legal Persons and Individual Entrepreneurs during State Control Checks." Fourteen varieties of checks turned out to be outside the requirements of the law in effect. Thus, the checking performed by the licensing agencies remained weakly formalized, or else not formalized at all. The police and the tax authorities retained the right not to limit themselves by the requirements specified in this Law.

In August 2002, the Federal Law “Concerning State Registration of Legal Persons" went into effect; its ratification had been predetermined as far back as the first part of the Civil Code, which contained a reference to such an enactment.

The Law is based on implementing the principle of registration as notification of legal persons in a single "one-stop shop" while raising founders' responsibility for information submitted at the time of registration. Resistance on the part of certain offices notwithstanding, it became possible to cut down registration time periods by means of giving up verification of whether founding documents correspond to the law

\footnotetext{
${ }^{13}$ The existence of a clear and immediate threat to the consumer as a result of possible fraud on the part of the producer or seller of the good or service in the absence of an alternative system of checks or ways to ensure the requisite quality and security standards.
} 
currently in effect (especially considering that such documents have long since begun to be prepared according to widespread model specimens; the founders themselves are interested in their complying with the law, as are their long-term partners, if such partners there should be).

The problem remains unsolved of the many adjustments in investment projects. A bill was prepared, proposing amendments to the Law "Concerning Investments"; this introduced the "one-stop shop" principle during project adjustment. In addition, the ideational framework was developed for a bill detailing the adjustment procedure and proposing the "privatization" of this type of activity. The work itself is governed by rigid rules by check time deadlines and the responsibility of the party performing the check for any damage incurred. Checking the degree to which projects conform to all kinds of construction, sanitation, and other requirements will be performed more effectively by commercial expert groups in exchange for regulated pay. The state could continue simply to maintain the work level of these commercial groups and the systems of requirements per se. This venue was not pursued; the authorities' interest in carrying out further reforms dropped (reasons for this development will be discussed in Chapter 6).

Analysis of the consequences of implementing "de-bureaucratization" was performed by the staff of the Center for Economic and Finance Researches (CEFIR; based on surveys of entrepreneurs in a number of regions in Russia (Zamulin, 2002)).

But the positive evaluation by authors of the Organization of Economic Cooperation and Development survey (OECD, 2005) of nearly all the reforms (of both the de-regulation and the court types) of the early 2000s is not borne out by any reliable proofs. The authors ascribe all problems associated with regulation quality after the introduction of the reforms to the fact that much still remains to be done.

\section{EGE (Unified State Exam): Attempt to Fight Interest Groups in the Absence of Media or Political Competition}

The purported objective of the reform in the system of examinations upon high school graduation and enrollment in institutions of higher education financed by the state budget was the struggle against corrupt admission practices. The blow was thus supposed to be delivered against groups of teachers and administrators in 
educational institutions, who used to sell access to some of the slots financed by the state budget.

Quite likely, this objective has been more or less completely achieved. The only legal alternative to the EGE as part of the enrollment proceedings today are statewide Olympic competitions. ${ }^{14}$

Yet the cost of "success" is impressive. A considerable part of the time spent in school is devoted to preparation for the EGE (all while even as it is, the quality of instruction in high schools continues to provoke expressions of ever greater consternation). Without special preparation, chances of passing the extensive and technically complex exam are slim. Also alarming are the widely discussed astounding EGE successes in regions heretofore not noted for their achievements. Positions of the regional bureaucracy turned out to be sufficiently strong by comparison with federal agencies' representatives at the local level; this was duly taken advantage of. Thus, in 2007, according to Federal Service for Supervision in the Area of Education and Science (Rosobrnadzor) statistics, ${ }^{15}$ amazing achievement levels by comparison with capital city regions were to be observed in the Republics of Mari El, Mordovia, Kalmykia, and the Samara and Chelyabinsk Oblasts. By contrast, such developed university centers as Perm Region and the Novosibirsk Oblast had only relatively modest achievements to show.

In just a few years, an enormous publishing business sector emerged, targeting the EGE (this includes materials produced by the publishing houses "Exam," "AST," "Eksmo," and "1S" Company, as well as similar materials printed by the old publishers, such as "Prosveschenie" and others).

\section{Special Interest Groups Abroad}

M. Olson $(1995,2000)$ showed that in the absence of wars, large-scale repressions, and other shocks, interest groups sooner or later begin to develop rapidly in both democratic and authoritarian states.

\footnotetext{
${ }^{14}$ According to Federal Service for Supervision in the Area of Education and Science (Rosobrnadzor) data, in 2009, winners and prize recipients of the Olympic competitions numbered 21 thousand upperclassmen; this group accounted for $4 \%$ of the slots in institutions of higher education financed by the state budget. 1403 of these students were winners and prize recipients of the "All-Russian Olympics," a competition whose special discount privileges involve no time limit. See http://www1.ege.edu.ru/content/view/622/36/ .

15 http://www1.ege.edu.ru/content/view/508/185/.
} 
The capacity of the poorest strata of the population for supporting civil society i.e., for shouldering additional expenses to the detriment of what are to begin with their worse than modest resources - so as to promote cooperation or self-organization, is minimal. ${ }^{16}$ The limited resources are themselves often a result of the inability to organize - due to lack of skills or ability to communicate. Civil society always and everywhere was and is made up of the middle class, which uses its ability to selforganize both to defend its own rights and to obtain revenue payments. (De Soto describes a case of robbery committed against George Washington, the first US President, by his neighbors who seized part of his land (De Soto 2004). Stigler showed how different varieties of redistribution and regulation (minimal wages specified by law, for instance) mean profit for the middle class at the expense of the poor (Stigler 1970).)

\section{Interest Groups and Economic Growth}

In his paper on "The Rise and Fall of Nations," M. Olson attempted to explain tendencies to slow down and block modern economic growth by interest groups' activism. He showed that the conditions favorable to the development of these groups (including urbanization and number of years of peaceful development) are statistically connected to the drop in growth rates of the population's real income and other indicators of economic growth.

Thus, those states which had lost in the US Civil War turned out to be among the leaders in post-war economic growth. Success in the post-war (after WWII) development in Germany and Japan is also explained by the author primarily by referring to the weakening of old interest groups as a result of state collapse and weaker connections between business and the regime in power.

But the author offers no recipes for solving the problem of interest groups' hyper proliferation.

It should be noted that US record growth of the federal state apparatus under President F. D. Roosevelt was accompanied by the unprecedented - and unequalled since - diminution in the role of the court system (as a result of the pressure exerted upon it by the executive authority) and Congress (due to the drastic drop in the power

\footnotetext{
${ }^{16}$ The case of the Russian "nouveaux pauvres" fails to fit in with this rule, insofar as we are dealing with an era of significant, drastic changes and with people already disposing of certain connections and having certain cooperation skills at their command.
} 
of the opposition both quantitatively and qualitatively: for decades after losing in the 1932 elections, the Republican Party was unable to offer voters an attractive and effective alternative model for the development of the country).

For problems emerging on the way to the appearance and development of the media markets in the US in the 1930-50s, which provoked a serious long-term weakening of the competition for these markets, see Chapter 2.

It is also no accident that "quiet" Sweden is only rarely our source of information about the rightist Prime Minister's disagreeing to pay a tax to benefit a leftistpoliticized public TV network, but hear nothing about the negative impact which the Social Democrats, in rule for many decades, had on business. But Italian channels' monitoring can supply the observer with information about the corrupt conduct of Prime Minister Berlusconi, about the evil character and stupidity of the opposition members, since, unlike Sweden, both sides have their own TV centers (see Chapter 10 for further detail). When leftists are in power, the corps of judges and the public prosecution office are busy investigating charges made against the leader of the opposition, but during rightist rule, they quickly switch to the Prime Minister.

This makes it reasonable to conclude that when searching for other factors which advance the increase in impact of interest groups deterring economic growth, as a working hypothesis it is advisable to choose weak competition on the media market, and dependence or politicization of the court system.

\section{Monopolies Real and Virtual}

As D. Armentano has shown, problems with private monopolies' domination of certain markets tended to be solved automatically. In some cases (as in the "Standard Oil" case), they were practically solved a few years prior to the beginning of the legal process (with the crash of kerosene shares and, accordingly, shares of the company itself on the petroleum products market). In what follows we will return to assessing the reasonableness of the attempts made by the state to choose optimal market structures, regimes and rules of competition. Let it only be noted that problems due to the state aim to appoint the "appropriate" regime and correlation of forces on various markets cannot be solved as part of the self-development and selfdefinition of the market mechanism. It clearly requires political action and/or bureaucratic counter measures. 
The same goes, in part, for professional trade unions. This is in connection with the fact that in most countries of the world trade unions rapidly became politicized, turning into important members of leftist political coalitions. As a consequence, the last few decades have seen no instance of large-scale economic reform that the professional trade unions did not energetically resist. Accordingly, there is no example of successful large-scale reforms in the old Rule of Law democracies, which were not accompanied by substantial losses for the trade unions (limitations were foisted on procedures required for proclaiming strikes, "picketing" attempts were cut short, ${ }^{17}$ and so on).

The 2008-09 crisis in the US manifested the destructive impact of trade unions particularly vividly. Trade unions were the key element determining the inability to compete of the leading American automobile companies and most of their suppliers. This was due to the fact that trade unions aggressively - to the point of picketing obstructed purchases made from "non-unionized" firms. This state of affairs could lead to that, having "suffocated" the leading US automobile construction enterprises, the most powerful of the trade unions in this country will thereby have committed suicide, being deprived of a source of income. Such a development may later clear the market for the emergence of new, "non-unionized" companies in it.

It is also helpful to remember that the very notion of "monopoly" appeared and spread as a label for exclusive rights to some resource, or to running some business. These exclusive rights are granted and provided by the state. Initially, the question involved privileges granted by the state to individual businesses $\left(15-17^{\text {th }}\right.$ centuries: sea trade and colonial initiative by Spain, Portugal, and England (Kulisher 2004)).

\section{Privileged Sectors}

The first privileged sector consisted of the banks (back in the days of the "roving" and "stationary" bandits). In order to prevent the reservoirs kept "handy" for the ruler from emptying, feudal lords lent de facto support to bankers' stealing investments made "to be called for." 18 This laid the foundation of state support and legalization of "private reserving" practices perceived today as self-understood. Continuing these practices along with political-legal pressure put on banks so as to

\footnotetext{
${ }^{17}$ It should be emphasized that what is meant is the "picketing" practices in leftist Western trade unions as a forced siege of an enterprise; this is very far from the miniature version of a peaceful demonstration, which is what picketing is according to Russian law and observable practices.

${ }^{18}$ H. U. De Soto 2008.
} 
"simplify" the procedure of procuring credit for a priori insolvent voters is in essence a reflection of a change only in the organization of modern "roving bandits." Nowadays they unite in coalitions of non-taxpaying voters headed by populist politicians of the leftist or statist brand.

Leftist politicians have long since noted that the bank system can be used for centralizing management of the economy and interference in private life. Relatively fresh successful initiatives are international campaigns on behalf of laws for the prevention of legitimization of criminally obtained income. Then again, long before these, the law urged citizens to keep their resources in banks, and to rely exclusively on these last to conclude a variety of transactions. Concern about consumers' reasonableness is expressed rather selectively in this area. It does not affect the widespread practice of extending credit for consumer spending. Debt incurred through such credit poses a universal threat to the stability of the bank system, on the one hand, and motivates the state to grant greater support to those banks which extended the greatest number of the worst credit deals, on the other. Such practices fit both the short term interests of bankers and politicians and the well-known Keynesian idea about damage caused by private amassments (the "paradox of thrift") and the beneficial effect which spending has on economic growth.

As De Soto (2008) has shown, state care as a rule cannot consist of control alone. Control inevitably weakens the ability of business to compete against less rigidly regulated foreign or shady businesses. By undermining the ability to compete of the business it controls, the state makes itself have to face the unpleasant choice:

To swallow up private enterprise altogether, assuming the full burden of responsibility for the welfare of every citizen, thus accepting the Soviet model; or

Compensate business in some way from the budget for the costs of the regulatory controls being imposed.

Considering that when the compensation amount is being decided upon, the information imbalance is in favor of the management of the company being looked into, rather than in favor of the state official, the former is nearly always able to foist what is an a priori inflated compensation amount upon the latter. 
According to Anne Krueger, to the question about "Why does business not try to get rid of state tutelage?" one entrepreneur replied, "As long as we are subjected to checks and controls, we will never be broke." 19

The problem can be solved if decisions are forced upon business, along the lines of arbitrarily dictated tax payments. But this venue rapidly and inexorably leads to the dilemma already indicated: the Soviet model or full compensation payments.

A variety of the same road can be travelled by setting up numerous state enterprises in branches and markets protected from rigid competition by formidable entry barriers. $^{20}$ The possibility of seeing part of its profit confiscated is “compensated" for by a privileged position enjoyed by an enterprise on the market. It should be noted that economically this option is worse than dotation pure and simple (as indicated by the simplest models in microeconomics).

Regrettably, the temptation of solving social problems in this way was not avoided even in the US, a country where state control and redistribution do not enjoy anywhere nearly the same extensive public support as in Europe. Thus, excess tax burdens for large corporations in Europe are partly compensated for by measures taken to encourage exports (something that costs the budget more than $\$ 50$ billion per annum). The beneficiaries of these measures are the selfsame large corporations. ${ }^{21}$

\section{“Overly Protected” Property Rights: Copyright}

In our view, the most convincing arguments wielded by critics of copyright involve instances of ugly law enforcement practices, in which violators debatably guilty of minor legal infringements are subjected to monstrous penalties (such as deprivation of freedom for many years). Most claims made against large corporations operating in the software products market (as well as most of the claims made by such corporations against each other) stem from the same problem.

Attention paid by the state to defending intellectual property, in whatever way motivated, cannot offer this branch of state functioning real advantages as compared, for instance, with those areas which are intimately connected with proprietorship of land. But, given comparable opportunities of defending an operations system disk and

\footnotetext{
${ }^{19}$ From a speech by A. Krueger (First Deputy Managing Director of the IMF) in Moscow in December 2001.

${ }^{20}$ For example, in the case of Russia, by means of barriers having to do with licensing. See Kuznetzov, Luzan, Stasyuk, et al. 2004.

${ }^{21}$ For analysis of this phenomenon and the damage it spells out for the economy see: Slivinski 2007.
} 
a plot of land, the de facto burden and expenses for the owner turn out to be far greater in the case involving land.

\section{Struggling against Interest Groups in the Experience of Other Countries}

Most forms of state control of entrepreneurship which presuppose extra spending by enterprises without budgetary compensation can be seen as a quasi-tax. That is, these are unfinanced spending obligations, or - as per Anglophone terminology, "unfunded mandates" (dues not provided for). At the same time, in accordance with practice already become familiar, control standards are set not by parliaments, but by offices of the executive authority.

Under these conditions, the chief direction taken by reforms of the state control system in OECD countries ${ }^{22}$ became the requirement of coming up with a quantitative analysis of alternatives to edicts ratified anew, with the analysis having to be done from the point of view of minimizing costs and maximizing profits, as well as regular analysis of the socio-economic effectiveness - and, in cases of lowered effectiveness, of revision - of norms currently in effect. ${ }^{23}$ At the same time, a methodology was developed for conducting in-depth formalized studies (surveys) aimed at analyzing effectiveness problems in state policy for regulating economic management (Regulatory Impact Analysis - IRA) from the vantage point of the correlation of costs and benefits (cost-benefit analysis). ${ }^{24}$

When a formalized system of state management is introduced, crucial is the institutional mechanism which is supposed to control the legislation come up with by the offices. With this in view, the US experience is particularly interesting; it was largely made use of later by Canada, Australia, and other OECD countries. Its principal feature consists in singling out agencies authorized to perform control activities (including the right of veto if necessary) vis-à-vis the socio-economic effectiveness of regulatory standards enacted at the official level.

\footnotetext{
${ }^{22}$ Organization for Economic Cooperation and Development, with a 34-state membership. See: http://www.oecd.org .

${ }^{23}$ Recommendation of the Council of the OECD on Improving the Quality of Government Regulation (Paris, 1995); The OECD Report on Regulatory Reform (Paris, 1997).

${ }^{24}$ The Regulatory Impact Analysis: Best Practices in OECD Countries (Paris, 1997).
} 
Thus, the appropriate authorization was given in the US to the administrativebudgetary management, which included the Office of Information and Regulatory Affairs (the OIRA). ${ }^{25}$ Disagreements between this and other federal agencies are adjudicated by the President or Vice-President of the country.

In addition, duties pertaining to controlling observance of requirements of minimizing small enterprise expenditures in the course of the ratification of normative decrees of the regulatory kind are taken on by the Office of Advocacy of the Small Business Administration. ${ }^{26}$ Of interest in this connection is the experience accumulated in the course of conducting permanent panel studies which make it possible maximally to evaluate the spending and the results of various regulatory standards vis-à-vis small businesses. In accordance with the Small Business Regulatory Enforcement Fairness Act (1986), the agency, functioning in the capacity of an amicus curiae, provides support for private individuals and organizations when they go to court, demanding the removal of ineffective regulatory standards as something not in accord with the requirement about minimizing spending for small businesses. $^{27}$

According to the agency's evaluation, the load foisted upon small business was successfully reduced as a result of revision studies of regulatory standards vis-à-vis small entrepreneurship: in 1998, the load went down by $\$ 3.2$ billion, in 1999 - by $\$ 5.3$ billion, and in 2000 - by $\$ 3.4$ billion.

No less significant from the point of view of well-grounded enacted regulatory standards is the extension of the authorization of the representative offices of the regime. The 1995 Unfunded Mandates Reform Act required that Federal agencies prepare in writing the explanations of spending and benefits to be derived from regulatory steps capable of leading to greater spending by the state, the municipal offices, or the private sector (at least for $\$ 100$ million annually).

In 1996, the US Congress approved amendments to the Small Business Regulatory Enforcement and Fairness Act. It was decided that the regulation standards responsible for the annual growth of spending by $\$ 100$ million must be approved by Congress prior to going into effect. According to this law, beginning from the time of promulgation of a normative act, Congress has 60 days to study the

\footnotetext{
${ }^{25}$ The Paperwork Reduction Act, USA 1980 (US Federal law about cutting down the volume of bureaucratic work).

${ }^{26}$ The Regulatory Flexibility Act, 1980; Small Business Regulatory Enforcement Fairness Act, 1986.

${ }^{27}$ A third party, an expert.
} 
normative act in question, and, should the need arise, to put a halt to its going into effect.

Of interest is the practice of making an annual quantitative assessment of costs and benefits yielded by the regulatory standards in effect which are included as an attachment to the text of the US budget. ${ }^{28}$ Thus, according to the US Administrativebudgetary management report to Congress for $2001,{ }^{29}$ the cost of regulatory control in the social sphere (health care, security, and the environment) oscillates between approximately $\$ 150$ billion and $\$ 230$ billion annually. The cost of economic control (in the areas of transportation, energy, communications, and foreign trade control) was evaluated at approximately $\$ 230$ billion annually. The annual costs related to maintaining accountability of various kinds were estimated at $\$ \$ 160-195$ billion. The total cost of regulatory controls thus came up to approximately $\$ 584$ billion.

During the last few years, the process of entrenching institutions of effective state control has begun more and more persistently to be pursued in states with a transition economy, including Hungary, Poland, and Czech.

Thus, after implementing sequential programs, Hungary has managed to make significant progress in constructing an effective system of state regulatory controls. ${ }^{30}$

The first program (1989-1991), related to the initial stage of the post-communist transformation, was aimed at large-scale revision of out-of-date laws and sublegal normative acts. Two parallel de-regulating Councils were formed, one of them to look into normative acts affecting economic functions, and the other into injunctions affecting the functioning of state services, the government, and issues of state control of civil conduct.

During 1991-94, de-regulating processes in Hungary practically halted, but then, beginning in August 1994, after new parliamentary elections had taken place, the government began to implement a new three-year reform package.

\footnotetext{
${ }^{28}$ For further detail, see: V. Mau, S. Javoronkov, O. Fomichev, et al., Deregulirovanie rossiyskoy ekonomiki: Mekhanizm vosproizvodstva izbytochnogo regulirovaniya i institutzional'naya podderzhka konkurentzii na tovarnyh rynkah [De-Regulating the Russian Economy: Mechanism for Reproducing Excess Regulatory Control and Institutional Support for Competition on the Goods Markets] (Moscow: IEP, 2003); see $\quad$ http://www.iet.ru/papers/48/index.htm .

${ }^{29}$ Office of Management and Budget Office of Information and Regulatory Affairs. «Making Sense of Regulation 2001. Report to Congress on the Costs and Benefits of Regulations and Unfunded Mandates on State, Local, and Tribal Entities. 2001».

${ }^{30}$ Government Capacity to Assure High Quality Regulation in Hungary. Paris, OECD, 2000; see http://www.oecd.org/pdf/M00041000/M00041058.pdf .
} 
A specially authorized government official position was created for dealing with questions of modernizing the system of state management; a united Council for issues of de-regulating was formed. September 1996 saw the government ratify the program including 21 organized measures and based on OECD recommendations. The program was seen as the first stage of a long-term policy of shaping an effective system of regulatory governance. It concentrated largely on implementing the following measures in de-regulating:

Analysis and revision of proposed laws and sublegal acts defining the functions and capacities of state authority agencies in the de-regulating sphere.

Analysis and revision of existing (in force) laws and sublegal acts.

Analysis of effectiveness of ratified laws and instructions.

Providing a more effective implementation of regulatory procedures defined by the laws in force (administrative methods).

Encouraging and supporting of initiative by local authorities at the time of the implementation of de-regulating procedures.

Advancing new varieties of organization of services provided by the state agencies (outsourcing et al.).

A special government authorized official working jointly with the Hungarian Ministry of Justice prepared a list of recommended control operations and instructions aimed at finding the optimal solutions to regulatory issues at the official level in order to facilitate the implementation of these measures. In addition, the authorized representative recommended that new administrative units (departments) be formed in the various offices, which would be responsible for implementing the de-regulating policy.

Even though implementing this program did lead to an appreciable decrease in the administrative burden, the procedures offered did not provide for higher quality regulatory conduct.

In May 1999, based on the experience of earlier measures in regulatory management system reform, the Hungarian government proposed a new two-year program. At the same time, the objective of perfecting the regulatory system was built into the general program of raising state service system effectiveness, aimed at improving the quality of services provided by the state sector of the economy.

Program priorities included: 
Analysis and revision of authorizations and objectives of regulating offices;

Revision of regulatory mechanisms at the regional level;

Expanding the use of new (information) technologies in the state sector; and

Improving the quality of the administration's human resources.

Beginning in 1998, functions performed by the government special authorized official responsible for issues of modernizing the state management system have been transferred to the Ministry of Justice. A special structure took shape within the Hungarian government apparatus: a group of specialized experts providing preliminary specialized evaluations of normative de-regulating acts in process, assessed with a view to quality.

Contemporary Russia has taken into account neither OECD countries' experience in forming effective regulatory systems, nor the parallel kind of experience of the most successful states with transition economies. Raising transparency of conduct by regulating agencies of the executive authority remains a sine qua non for ensuring the effectiveness of this kind of activity. In connection with the proposed project Program of Socio-Economic Development of the Russian Federation for the medium-length term (2003-2005), measures for activating the policy prepared by the Ministry of Economic Development for de-bureaucratizing the economy included:

Introducing procedures for grounding the need for state interference, indicators of effectiveness expected, calculation of expenses, and procedures for public defense of the need for state interference;

Transferring authorization for defining regulatory standards, which entails a considerable volume of spending for the parties involved in the management, from the offices up through the government and Federal Assembly.

Conditions for the success of the measures indicated are, naturally, acute political and media competition, without which it is impossible to provide unebbing motivation of political leaders on all levels vis-à-vis damage done to business and due transparency of introduction of normative acts. Absence of these factors lowered appreciably the effectiveness of attempts to make use of the experience of developed countries (OECD countries) in Russia.

\section{Ensuring Openness of Work of State Authority Agencies and Interaction with Civil Society}


The principal objective of introducing administrative reform is raising the effectiveness of the work done by agencies of state management. To achieve this, it is essential to ensure the transparency of the state management system for citizens, as well as the system's interaction with organizations of civil society.

Thus, State Service Reform Conceptualized included:

Ensuring the option of citizens' involvement and the involvement of civil society structures in the decision making process;

Providing with objective information about steps taken by state agencies and state employees in accordance with federal law which prescribes specific rules for action taken by agencies of state authority;

De-bureaucratization of relations among state employees, Russian Federation citizens, and civil society structures.

Confirming the option of operative access to any records available through agencies of state authority; in recent years, this has become one of the inalienable civil rights entitling citizens in the civilized world to take conscious part in the political process. ${ }^{31}$

Along with access to various analytic materials, order of this kind normally provides access to proposed normative acts at the sublegal level, as well, thus permitting citizens to take part in discussing them up until the time of their definitive ratification. By 1980, such laws had been ratified in $20 \%$ of the OECD member countries; by 1990, in 40\%; and by 2000 in as many as $80 \%$ of the countries. ${ }^{32}$ As of July 2002, the same legislation has been accepted in 45 countries of the world; it was at that time also at the stage of development in more than 30 others. ${ }^{33}$

For instance, in the US, the Freedom of Information Act (FoIA) was ratified back in 1966, while a sizable number of other states ratified similar laws only during the last fifteen or twenty years. Besides, in most of the laws ratified, the requirement became commonplace that state agencies' information must be posted on the internet.

\footnotetext{
${ }^{31}$ With the exception of data categorized as state secret, and some others.

${ }^{32}$ Citizens as Partners: Information, Consultation and Public Participation in Policy-making. OECD, 2001. http://www.oecd.org/EN/documents/0,EN-documents-461-nodirectorate-no-15-no-11,00.html.

${ }^{33}$ A detailed survey of legislation in countries of the world and references to the complete texts of the normative acts are provided in the report by the international organization Privacy International. See Freedom of Information and Access to Government Records around the World by David Banisar; http://www.freedominfo.org/survey/ . See also: Rossiyskiy $i$ zarubezhny opyt pravovogo regulirovaniya dostupa grazhdan $k$ pravitelstvennoy informatzii [Russian and Foreign Experience of Legal Regulating of Citizens' Access to Government Information] (Moscow, 1999). See http://www.ksdi.ru/p-readhall-opit.shtml .
} 
Thus, in the US, requirements along such lines were confirmed by means of a special law: the Electronic Freedom of Information Act (1996).

By means of digitalization of an enormous block of information at the disposal of the executive and representative agencies of the authorities, an appreciable reduction in the cost of disseminating documents is brought about, along with participation in legislative activity by a considerably greater number of interested persons and experts than had been possible ever before.

Thus, in the US, beginning back in 1995, the order of presenting work documents to legislators has changed: members of the House of Representatives began to receive these documents only after they would be made available to the press and the public. For three weeks following the moment a decision is made, all documents (analytic, statistical, texts of amendments, and so on) are automatically published on one of the Congressional websites. ${ }^{34}$

Practices of this kind also became widespread in countries with transition economies, including post-Soviet states. Thus, the Public Information Act was ratified in Estonia in 2000, obligating state and territorial agencies and legal persons possessing any kind of property and offering services to the public (such as education, medical, social, utilities services, et al.) to provide the required information within 5 days, including electronically.

Pride of place in the law concerning free access to information belongs to issues of ensuring law enforcement. In Belgium, Iceland, Ireland, the Netherlands, and New Zealand, supervision of law observance is performed by an ombudsman, and in Canada - by a special "information commissar."

In Russia, too, a great practical step has been taken in this direction. The decree by the government of the Russian Federation "Concerning Providing Access to Information about Activities of the Government of the Russian Federation and Federal Agencies of the Executive Authority,” dated February 12, 2003, №98, contains a long list of data required to be posted on the internet, as based on the best of foreign practice. The list includes texts of legal bills in the process of development, information concerning purchases made, data about results of checks, and more.

In March 2003, the State Office of Economic Development and Trade proposed for general discussion the Federal Law Bill "Concerning Providing Access to

\footnotetext{
${ }^{34}$ http://thomas.loc.gov/.
} 
Information about State Agencies and Agencies of Local Self-Government," which had been okayed with the RF Government. ${ }^{35}$ The bill applies the principal elements of the decree mentioned above to authorities at the regional and the municipal levels. The legislative bill notes the need to ratify separate legal acts which would control the right of access to information about court activity and the judicial and representative authorities.

Certain ways of democratizing political consulting practices became clear along with information disclosure pertaining to the activities of executive authority agencies. The first step taken in ensuring effective interaction between executive authority agencies and civil society organizations was the promulgation of the order of the Russian Government, dated March 7, 2002, №278-r, which ratified the list of measures taken by the RF Government to implement the results of the Civil Forum:

Creating work groups jointly with public organizations;

Including public organization members in makeup of counseling agencies at federal executive authority bureaus;

Creating public councils to observe the implementation of federal target programs;

Resolving questions of providing non-commercial public organizations with access to competitive procedure in connection with taking advantage of budgetary financing opportunities.

However, as the relative weight of the legislative branch of power went down since 2003, these initiatives were accorded no due follow up development.

A step in the right direction here could have been the practice of including in public information resources not only official proposals of normative acts, but also alternative versions accompanied by commentaries.

As an example, we can refer to the Regulations.gov site, which is supported by the US government. ${ }^{36}$ The site allows every citizen not only to acquaint him or herself with the law bill proposed for legislation in the regulatory sphere, but also to publish original comments, as well as to be exposed to comments made by other citizens.

\footnotetext{
35 Federal Law Bill "Concerning Providing Access to Information about the Activities of State Agencies and Agencies of Local Self-Government," http://www.economy.gov.ru/projects.html ; Federal Law of February 9, 2009, № 8-F3, went into effect beginning on January 1, 2010.

${ }^{36} \mathrm{http}: / / \mathrm{www}$. regulations.gov/.
} 
Practice of this kind is based on compulsory open publication of comments made by the public on legislative proposals by the executive authority, something provided for as far back as the US Administrative Procedure Act of 1946. According to this document, the Federal Register, a national bulletin, publishes a piece containing the text of a given proposed sublegal act, as well as the reasons for the regulatory agency's proposing such an act. Using the data, surveys, or arguments provided in the letter, all those who may be interested, including non-residents, have the opportunity to take part in the process.

In accordance with the interpretation given to the Federal Administrative Procedure Act by the Federal courts, public comments appear as an official document. The regulatory agency must present public comments in the course of discussion, before the final version of the decree is endorsed. Depending on the importance of the legislative act, the regulatory agency may receive dozens of thousands of public comments.

Such an approach appears to be the most justified. It may be noted that in making political acknowledgement of information disclosure, Russia has made considerable progress; even so, her lagging behind in practice still leaps to the eye.

The effect of information disclosure through the internet is directly bound up with the country's level of digitalization; that is, the extent to which it is outfitted with computer technology and opportunities of plugging into information networks.

Information-communication technologies do not only provide the technical opportunity for decentralized access to any content-rich information at minimal cost; they also lower the costs of setting up and maintaining multilateral communications among persons participating and/or interested in participating in political decision making, thus creating the grounds for extending and democratization of existing political networks. ${ }^{37}$

\section{Certain External Effects of Success in the Struggle for "Defending the Population"}

The thicker and the more intensive the defense of the inhabitants from all thinkable and unthinkable threats, the more evident are the symptoms of problems in

\footnotetext{
${ }^{37}$ See A. Shadrin, "Informatzionnye tekhnologii $i$ sovershenstvovanie sotzialnyh institutov" ["Information Technologies and Perfection of Social Institutes"] in: I. Semenov, Moscow Carnegie Center, ed., Internet $i$ sovremennoe obschestvo [Internet and Modern Society] (Moscow: Gandalf, 2002). See http://pubs.carnegie.ru/books/2002/08is/default.asp?n=04.asp .
} 
supplying the pure public good of "justice." It is no accident that sincere attempts by the authorities to weaken administrative pressure on business in Russia unswervingly yielded the meanest of results.

The very acceptance by society of the admission that an economic agent is a creature having no common sense, experience, or responsibility, creates the need for some "external management." At stake is the majority of humanity, so claims made by the state to be functioning as such a manager appear quite natural. ${ }^{38}$ That is, the decomposition and spoiling of the legal system are the attendant companions (sometimes the reason, sometimes the consequence, and sometimes both the one and the other at once) of the admission of citizens' inability to take concerted action.

Upon acknowledging such an admission, it is natural to expect the sphere of discretionary management to extend gradually, due to the great number and unexpectedness of threats from which the state "is supposed to provide defense." The inability of one side to take concerted action and its reliance on the other as a permanent expert or "impartial" witness to an ever growing range of questions and cases puts the court in a condition of informational dependence on the apparatus of the executive authority. This makes citizens' triumph over state agencies all the less likely; that is, the court gradually becomes more dependent on the state. Even in a standard situation, given a normal attitude toward citizens, it is simpler to appeal to state officials as experts and witnesses (or more exactly, these last themselves willingly and in a disciplined fashion offer their services). Accordingly, more and more often, positions espoused by certain judges at the beginning, and later by the entire judicial assembly, shift, a development which begins to predetermine the intellectual tradition and stereotypes among judges. The most dangerous of these stereotypes is taking the formally competent subject as incompetent in fact.

Creation of a "new entrepreneurship" having to do with serving the authorities' supervisory functions ${ }^{39}$ is just one example of the general change in incentives when particular cases are observed of success in obtaining income protected from risk. This derives from a monopoly brought about by the government's fencing in the market to prevent entry by any firm except for the one arbitrarily chosen.

\footnotetext{
${ }^{38}$ The opposite approach, which presupposes that economic agents are endowed with "common sense," limits state interference to a minimal set of regulations.

${ }^{39}$ For instance, companies "serving" state demands that entrepreneurs must comply with concerning accountability, certification, quality control, and so on. For further detail, see, inter alia, Auzan 2002.
} 
Another instance is cited by De Soto (2008). Companies accepting state regulatory control (prices, all taxes, "social responsibility," et al.) lose their ability to compete, themselves appealing to the state so that it should punish those among their competitors who eschew the burden indicated, or at least that it should compensate them for losses (profit not fully realized up to the "normal" level).

\section{Or Competition, or Anti-Monopoly Policy}

The state's ability to support competition on the goods markets is empirically confirmed just as strongly as the state's ability to plan production and to specify "scientifically grounded" prices.

But in recompense, the state's ability to "appoint" and support the "winners" in market competition - that is, to foist certain goods offered by certain companies on the consumers - leaves no doubt. Objectively, a state employee - both a real one, and the model for one as described by Niskanen - is interested in a relationship of mutual dependence with business, rather than one of unilateral dependence of the state on large independent private taxpayer companies. This is why exchanging privileges for the right of the state to interfere in company affairs, and the right to interfere for guaranteed safeguards against bankruptcy and fencing in the market from independent competitors is the logical consequence of the very existence of state services as a strong corporation independent of society (for further detail see Appendix I to Volume III).

In his "Antitrust. The case for repeal", D. Armentano surveys the history of the distribution of "anti-monopoly" practices in the US. ${ }^{40}$ The author demonstrates the utter uselessness of the measures taken from the point of view of providing a competitive environment, as well as that the introduction of a standard and its going into effect in reality (almost 20 years after the formal ratification of the Sherman $A c t^{41}$ ) did not coincide in time. This had to do with the political pressure of interest groups who were far from thinking about defending consumer interests. In essence, both the legislation and its active implementation were a way to punish the winners of a competitive race, i.e., often a way to punish the consumer.

According to V. Novikov's ideas (Novikov, Luzan 2003; Novikov 2004), the only requirement in Russian law aimed at defending competition, is the one which forbids

\footnotetext{
40 Armentano 2006.

${ }^{41}$ The Sherman Act was the first US anti-monopoly law, enacted in 1890.
} 
agencies of the authorities to take steps to limit competition. The personal experience accumulated by the author of the present chapter (K. Yanovskiy) in an anti-monopoly office completely confirms this hypothesis: in the early 1990s, the Anti-Monopoly Committee more than once was embroiled in conflicts with branch and regional authorities, including the powerful ones in Moscow, often preventing further state interference in either market processes or the process of privatization.

Anti-monopoly policy criticism also seems well grounded from the point of view of the Austrian School, considering that very strong allowances are made for the market model with "perfect competition," while the role and the real market functioning of entrepreneurs in finding arbitration and profitable project options are ignored. The notion that a mistaken and imperfect policy of the state is chosen due to a mistaken and imperfect theory seems less convincing than that decision makers are motivated to opt for that policy which extends the sphere of formal competence (i.e., influence) as well as the spectrum of decisions made, i.e., the policy which expands the authority of the officials.

The situation on any market must be considered in somewhat different perspective, not the way this is done in microeconomics textbooks. It is dangerous to make use of a picture from a textbook, because, presupposing total information access, textbook pictures endow not only individual subjects with this, but also the state. In a textbook picture the state appears as a unified economic agent with a single will and ability, and, what is most important, with motivation for taking action so as to maximize the public good.

Long-term ineffectiveness of the monopoly makes it thoroughly vulnerable; it then becomes only a question of time, when someone should turn up who may be interested in assuming the weakened company's place on the market. Rationality, a primitive version of which is applied by the defenders of monopoly theory in modern mainstream microeconomics to defend anti-monopoly policies, does not presuppose omniscience in real life. Rationality for the real market agent consists in that in making a choice, the agent takes into account the cost of knowledge and the cost of information (which is often quite high). At the same time, information about profit to be derived from possessing this or that particular knowledge is not always universally accessible. Monopoly managers also do not have complete information at their disposal. This is why monopoly as such is unable at any given moment to choose the 
best strategy for keeping competitors away from the market. These last may, for instance, turn out to be players from other, contiguous sectors.

H. Ford did everything to ensure that his product would be "homogeneous" (as on the competitive market). ${ }^{42}$ His competitors were producing automobiles of different colors with different types of body and carriage structure. They pushed Ford's firm out to second place, even though it seemed to have been "doomed" to become a monopoly due to its being technically in the lead, as well as due to the entrepreneurial genius of the owner and growing returns from the scale of production. The market had become quite competitive, and so it remains to this day, mergers and buyouts notwithstanding.

Much earlier, the same fate had overtaken Standard Oil with the discovery of new oilfields and the shift of demand from kerosene to gasoline. As Armentano notes, the famous precedent decision to split the firm came nearly $10(!)$ years after the firm had first begun to lose ground on the market.

The state-public struggle against monopolies brings in its wake both consciously motivated misuse harmful to the public good, and errors in choice of place, time, and even targets of attack. The very idea of attacking the most successful entrepreneur (if he has not achieved success via being connected with the state machinery) is philosophically understandable. Opting for the strategy of "Beat the one who is strong, aid the one who is weak" can only lead to increase in the number of firms, volume of "bad credit," and interference in bank activity, all so as to protect unsuccessful small entrepreneurs (this time not from a powerful rival within the same branch of the economy, but rather from the "greedy banker").

This idea is even more understandable from the point of view of public choice theory. Out of two players - one successful, the other not - the latter naturally is the more strongly motivated to appeal to the state for aid in "protecting" him from his competitor. Such was the case, for instance, in the US, when the state destroyed the railroad business, a process halted only at the turn of the 1970-80s. Small and ineffective carriers organized in the 1930s against the strong and the successful and achieved considerable long-term deterioration of the situation, which then rapidly improved once the regulatory control had been abolished.

\footnotetext{
${ }^{42}$ The famous blanket summary by H. Ford, "Any customer can have a car painted any colour that he wants so long as it is black".
} 
If profits on some market unencumbered by entry-exit barriers become higher than in other branches, capital will flow into it, creating tangible competition and lowering prices - provided, of course, that the state does not proclaim, for instance, that security standards and requirements are met exclusively by one single company's teapots or refrigerators.

Now, should the state take it upon itself to solve the problem, most likely it will destroy the largest firm having the most effective production, and thus achieve universal lowering of quality and security levels while maintaining a semblance of competition; this has already been the case with the railroads. A plethora of examples of state struggle against success in business resemble somewhat the fight against "disproportionate use of force" (i.e., against success and victory) on the battlefield, making it impossible to put down violence and terror in an effective manner.

In real life, unsuccessful entrepreneurs are always more numerous than successful ones. And even a uniquely prosperous businessman can, given time, stop being successful (take the case of G. Ford). So if anything does, in fact, need protecting by the law, then this is not the "form of competition," but competitive market rules of the game. They are founded upon private property, private property owners, and the prohibition against interfering in their business, unless life or property is threatened. Life, health, and property need to be protected by means of constitutional guarantees impossible to overcome even when impacted by emotions against some Gill Gates or Ford.

As an example, consider the announcement made by A. Pibalgs, EU Commissar for Energy Issues. Comparing Gazprom and Microsoft, he stated that Microsoft is worse, insofar as it "controls $100 \%$ of the market," 43 i.e., Pibalgs compared a statecontrolled monopoly disposing of resources as per state orders and subsisting at the expense of society as a whole, with a private company putting on the office and operations systems market a product incomparably more user-friendly and convenient (from the point of view of the average user), and thus, of higher quality, than the products offered by its competitors. According to anti-monopoly logic, this should be severely punished. The "fault" the company is charged with is the very fact of its might, rather than particular misdemeanors or legal violations.

\footnotetext{
${ }^{43}$ http://www.reuters.com/article/governmentFilingsNews/idUSL1560812020071015.
} 


\section{Corruption Effectiveness Limit Model}

\section{Assumptions}

Corrupt transactions are mutually profitable (those which are not should reasonably be classed together with simple extortion or robbery ${ }^{44}$ ).

Information concerning contracts and their profits, albeit in non-individualized format, becomes common knowledge, i.e., there is total information awareness.

Bribes can with a certain degree of probability entail a penalty.

The wellbeing of society is determined by the number of mutually profitable contracts.

A corrupt transaction under Rule of Law entails profit for the parties. The profit is obtained by means either of redistributing resources in favor of the parties to the transaction, or of setting up barriers which third parties must overcome in order to enter some market. In this case profit results from raising the profit standard for firms admitted to the market.

A corrupt transaction in this situation harms third parties. An additional factor in the damage is the undermining of trust put by market agents in state institutions and in each other. This raises transaction costs in the economy and assessed project risk levels. All these things prevent some mutually profitable transactions from being concluded (among agents least inclined toward risk) and lowers general utility. ${ }^{45}$

Insofar as in a society in which authority is based on force and legitimates itself by means of force (Rule of Force), most mutually profitable contracts are prohibited. The typical corrupt transaction becomes payment for circumventing the barrier, for concluding a prohibited mutually profitable transaction which has no negative external effects in the normal sense of the term. Since agents are rational, we presume that economically active citizens in society of this kind put zero trust in the legal system as such; instead, they resolve all problems precisely by means of bribing authorized officials representing the state, which is a priori taken to be the enemy.

Political-economic consequences of long-term corrupt practices are that resources are accumulated by private persons, fortifying their positions in their dealings with the state; provided, of course, that the state is not willing to resort to mass repressions in

\footnotetext{
${ }^{44}$ Klyamkin \& Timofeev 2000. The authors cite two traditional "crafts": bribery and extortion. In the model in question only the first of these is involved.

${ }^{45}$ Shleifer \& Vishny 1993.
} 
order to confiscate these resources (thus preventing corruption of this kind), while economically active agents are not willing to take up arms to resist. ${ }^{46}$

\section{Rule of Law State and "Universal Welfare State"}

The "universal welfare state" was sired by the common Rule of Law state. But because of the rate for defending the interests of most agents (households, small enterprises) from certain "harmful" market transactions (i.e., transactions involving a "negative external effect"), it sets up an entire series of barriers. But these barriers also prevent the realization of some transactions having no negative external effects.

Independently of the incentives for those setting up the barriers (aim to receive administrative payments or achieving "universal happiness"), the number of transactions and, accordingly, wellbeing, both go down. Cases when limitations really do bring down the negative external effects form the rare exception. ${ }^{47}$ Setting up barriers of the indicated kind also undermines agents' trust in the state and in each other, yielding more or less well founded suspicions of lobbying in support of measures to be enacted against competitors. This negative effect may be coextensive with the sum total effect of the total number of corrupt transactions having to do with circumventing some barrier. This number would equal the number of enterprises encountering the established barrier. Penalties for bribery deliver harsher blows against attempts to circumvent a barrier than does the barrier's mere establishment (for the simple reason of the greater number of transactions of the "circumventing" type, with comparable levels of crime detection for both). Depending on the "stakes" of the bribe and the penalty level, a boundary will emerge, which will prevent the aggregate public welfare from changing even when yet another transaction of the circumventing type is concluded.

\section{Simplified Model}

\footnotetext{
${ }^{46}$ European history provides a number of instances when citizens approached modern standards of Rule of Law statehood, alternating bribing the state with bargaining and even with armed resistance. Consider the period from the Middle Ages until the Dutch Revolution.

${ }^{47}$ As an example of limitations of this kind, which prevent negative external phenomena, we may cite penalizing entrepreneurs for hiring illegal immigrants. However, not only in Russia, but often in old Rule of Law democracies, as well, such measures prove ineffective. One of the reasons is nothing other than corruption; another - also in consonance with the model - is the low quality of the legislation. Labor market "overprotection" undermines the tax base of the authorities. De-regulating it is politically complicated. But "political costs of liberalization" of law enforcement practices vis-à-vis violators may turn out to be quite reasonable.
} 
Let us introduce some simple assumptions.

A great many voluntary and mutually profitable transactions are in existence, which are accessible to economic agents.

Let $\alpha$ be the share of transactions involving negative external elements, whose size does not exceed the private profits for the parties involved in the transaction. Transactions of this kind bring public welfare down.

Let $A$ be the total losses for society in case all transactions belonging to set $\alpha$ are realized $(A>0)$.

Then, accordingly, $(1-\alpha)$ signifies those transactions which, if they are realized, raise public welfare (which is measured as joint profits for all citizens).

Let us denote by $T$ the overall gain from the implementation of all transactions.

Let us consider two types of society.

«Rule of Law» is the society in which all transactions are permitted except for those which are manifestly prohibited.

«Rule of Force» is the society in which all transactions are prohibited except for those which are manifestly permitted.

In a situation of complete freedom, when all accessible transactions (profitable for all those party to them) are realized, public welfare is determined according to the following formula:

$$
W=T-A \text {. }
$$

1)Let us suppose that in a given society limitations are imposed on transactions belonging to set $\alpha$ (that is, all transactions are forbidden which lower public welfare).

Then public welfare will increase up to

$$
W=T .
$$

In this situation, any violation of a prohibition leads to decreasing public welfare, since a transaction is then implemented which decreases public welfare (due to negative externals exceeding the private gain of the parties to the transaction).

2) Let us consider the situation in which all transactions are a priori prohibited, except for a narrow range of permitted transactions $(\beta)$. Accordingly, $(1-\beta)$ stands for the set of prohibited transactions.

Let us suppose that the set of permitted transactions contains no transactions involving negative externals, i.e., all transactions in $\alpha$ are also forbidden. Hence, 


$$
1-\beta>\alpha
$$

Violation of the prohibition may lead to that public welfare can both grow and drop (if a transaction involving negative externals is implemented).

Let us introduce the following concepts:

$A$ / $\alpha N$ - losses incurred due to the realization of one transaction with externals;

$T /(1-\alpha) N-$ gain from the implementation of a transaction not involving externals;

$N$ - total number of transactions accessible.

If at the moment of prohibition violation all transactions (both ones with negative externals, or the "bad ones," and ones without negative externals - the "good ones") are equally probable, then the likelihood that a "good" transaction will be implemented at the time of prohibition violation equals

$$
P g=(1-\alpha-\beta) /(1-\beta),
$$

while the probability that a "bad" transaction will be implemented at the time of prohibition violation is

$$
P b=\alpha /(1-\beta) .
$$

Society then gains from prohibition violation when the expected gain from the implementation of forbidden "good" transactions exceeds the expected loss from the implementation of forbidden "bad" transactions.

Let us perform certain transformations:

$$
[(1-\alpha-\beta) /(1-\beta)] \times[T /(1-\alpha) \times N]>A \alpha /(1-\beta) \alpha N,
$$

or

$$
[(1-\alpha-\beta) /(1-\beta)] \times[T /(1-\alpha)]>A /(1-\beta),
$$

or

$$
T[(1-\alpha-\beta) /(1-\alpha)]>A,
$$

or finally

$$
T[1-(\beta /(1-\alpha))]>A \text {. }
$$

All this while $\beta=(1-\alpha)$ is precisely the situation described in P. 1 , when the set of permitted transactions $(\beta)$ coincides perfectly with the set of "good" 
transactions (transactions not involving negative externals) $(1-\alpha)$. In this case, the expected gain in public welfare from the violation of the prohibition against transactions will be zero:

$$
[1-(\beta /(1-\alpha))]=0
$$

while the inequality in (3.1) will not be implemented whatever the value of $T$, since $A>0$.

If $\beta$ is relatively small (i.e., only a small part of the transactions are permitted), while the gains in public welfare from "good" transactions are overall greater than the losses incurred by the "bad" (that is, $T \gg A$ ) and only an insignificant part involves externals (i.e., $\alpha \rightarrow 0$ ), then

$$
\beta /(1-\alpha) \rightarrow \beta
$$

and prohibition violations may turn out to be profitable:

$$
T(1-\beta)>A \text {. }
$$

Analyzing the expression in (3.1) can be done from positions espoused by Rule of Law society, where everything which is not forbidden, is permitted.

If we suppose that $\gamma$ is the set of prohibited transactions, then the probability of a "good" transaction at the time of prohibition violation will be

$$
P g=(\gamma-\alpha) / \gamma
$$

while the probability of a "bad" transaction at the time of prohibition violation will be

$$
P b=\alpha / \gamma \text {. }
$$

In expression (3.1) the condition ensuring that society begins to gain from the opportunity to violate prohibitions, will be:

$$
T[1-(1-\gamma) /(1-\alpha))]>A \text {. }
$$

In case $\gamma=\alpha$, society will a priori lose by violating prohibitions, independently of the ratio of $A$ to $T$. But as the number of prohibitions grows (that is, as $\gamma$ becomes larger), the gains to be expected from violating these prohibitions also increase, since the likelihood that a given transaction will prove profitable for society also becomes greater. 
The largest possible quantity of prohibitions $\left(\gamma_{\max }\right)$ beyond which further growth in prohibitions makes rule violation profitable for society, is determined when gains and losses expected from prohibition violation are equal.

We perform the transformations:

$$
\begin{gathered}
\left.T\left[1-\left(1-\gamma_{\max }\right) /(1-\alpha)\right)\right]=A \\
\left.\left[1-\left(1-\gamma_{\max }\right) /(1-\alpha)\right)\right]=A / T
\end{gathered}
$$

or

$$
1-A / T=\left(1-\gamma_{\max }\right) /(1-\alpha)
$$

or

$$
\left(1-\gamma_{\max }\right)=(1-\alpha)(1-A / T)
$$

or finally

$$
\gamma_{\max }=1-(1-\alpha)(1-A / T)
$$

If all transactions are "bad" $(\alpha \rightarrow 1)$, then the top limitation of $\rightarrow 1$ is independent of the ratio of profits $(T)$ and losses $(A)$. That is, even when prohibitions are high, violating them will not be profitable (insofar as all transactions are "bad").

If all transactions are "good," i.e., there are no losses due to externals ( $\alpha=0, A$ $=0$ ), then $\gamma_{\max }=0$. In other words, given any limitation unequal to zero, violating the given limitation will be profitable.

If losses incurred due to "bad" transactions are significantly lower than gains from "good" transactions (i.e., $A<T$ ), then the expression will look like this:

$$
\gamma_{\max }=1-(1-\alpha)(1-A / T) \rightarrow 1-(1-\alpha)(1-0) \rightarrow 1-(1-\alpha) \rightarrow \alpha .
$$

This means that in a situation when gains from "good" transactions overall exceed significantly the losses incurred due to the "bad," exceeding the level of regulating (i.e., increase in quantity of "prohibited" transactions) of the set of transactions involving negative externals leads to that violating the regulation in question becomes profitable.

In the situation described (when gains from "good" transactions are much greater than losses from the "bad"), violations will be unprofitable for society only at the regulatory level with the bounds of $\gamma_{\max } \rightarrow \alpha$ (i.e., within limits of the set of "bad" transactions). 
Returning to the example with Rule of Force society (in which everything is forbidden, and only a small part of the transactions are permitted), we can note that corruption (i.e., the possibility of concluding forbidden transactions) turns out to be profitable for society, while initiatives for fighting corruption can only make the situation in the country worse.

\section{Separation of Business from Power and from "Social Responsibility"}

One of the most valuable lessons offered to the most extensive groups of market agents (who suffer from losing jobs or the threat of losing jobs), is the understanding of what real "social responsibility" of business consists in.

The only "social responsibility" business has is stability in both providing goods and earnings. The most important thing expected of business by both workers and consumers is stable success. Anything running counter to this leads to the acquisition of lesser goods at the expense of losing greater ones.

It bears stressing that the burden of this responsibility is much heavier than the must of fulfilling the wishes of the authorities as if they were injunctions, especially when agreeing to obey injunctions is balanced out by the hope to be aided by the authorities in case business faces the threat of closing down. This is why a significant, if not the greater, part of entrepreneurs (except for the most competition-suited and successful) themselves willingly agree to assume responsibilities beyond the limits of their sphere of competence (responsibility for the social sphere). This is made quite worth their while if it exempts entrepreneurs from taking on all the risks that volatile markets involve (this last being the immediate task and natural responsibility of business).

V. Kayuchenko (2010) provides a survey of the "Social Auditing" and "Social Responsibility" Institutes, which had become widespread beginning in the US of the 1970-80s. Unlike this book's authors, the author of the survey sees this development as an exclusively positive one.

It should be noted that interest group pressure on business (primarily of the large enterprise type) with the aim of subjugating it to external "social" dictates began long ago. However, sensing the backing of powerful moral-religious justification behind them, late $19^{\text {th }}$-century business leaders could permit themselves outright, sharp 
comments a la Vanderbilt: "The Public be damned" 48 Economically and morally, such takes are grounded in that the true preferences of the public are reflected in the manifest demand for company services, rather than in a journalist's opinion.

The situation has changed drastically in the last 100 years. More than that, many large company managers have found that spending stockholders' money on bribing different groups of activists (the "public") is considerably easier than winning general acknowledgment and maintaining consumer loyalty by offering better quality goods and services at lower prices. ${ }^{49}$

This algorithm resembles the behavior of large companies intimate with the authorities in Peru, who bear something akin to the burden of "social responsibility," requiring in recompense that the government prevent their competitors from entering the market. Thanks to its compact size and well-known simplicity of the parties involved, this last example facilitates understanding the situation. ${ }^{50}$

The noted tendency of many businesses easily to agree to "non-profile" tasks or assignments makes demands for reform more insistent. Reform aimed at separating business from the authorities in power must be implemented such that it could remain stable despite counter-reforms and revision. Such reform is essential so that everyone could handle his or her own problems without blurring the bounds of personal and individual responsibility.

\section{Trap for an Irresponsible Electorate and Excess Government's "Responsibility"}

A certain share of the body of voters is willing to authorize the state to provide "defense of each and every single position." It is they that help reproduce the excess regulating. The greater the share of such voters, the easier it is for interest groups to fight for their goals. Accordingly, the interest groups themselves are in favor of increasing the number of these voters (we will consider this issue in greater detail in

\footnotetext{
${ }^{48}$ http://www.futureofcapitalism.com/2010/06/vanderbilt-the-public-be-damned; http://www.americanheritage.com/articles/magazine/ah/1989/6/1989_6_18.shtml .

${ }^{49}$ The author of the survey mentioned notes that thousands of "social" corporation reports are posted online at www.corporateregister.com. The companies themselves took part in developing forms and standards of accountability for "Corporate Social Responsibility" (CSR), such as AA1000 AS. The existence of an alleged economic need and usefulness of voluntarily assumed social responsibility can well be questioned based on the examples of companies such as Microsoft or WalMart. At the peak of their success, these companies were persecuted by the mass media, held up as examples of "socially irresponsible" enterprises. The motto of the second (addressed to consumers), "Save money. Live better," speaks for itself.

${ }^{50}$ De Soto 2008.
} 
Chapter 13). Weaker competition and crushing of market mechanisms which support high quality level intensify the appearance of lack of alternatives in this situation.

\section{Conclusions and Recommendations}

The mechanism determining how the expansion of special interest groups affects economic growth is described by M. Olson (Olson 1982; Olson 1995). Let us suppose that there is a possibility of redistribution initiatives and "defending the consumer" by means of regulation or establishing market entry barriers (such a possibility means absence of forbiddingly high costs associated with the corresponding decision making). These barriers are a burden for the majority of market agents and provide a gain for only a small group. If the group is motivated (the gains being large enough), while the majority is weak and disorganized (a single market agent's losses due to the introduction of a barrier are not great), then the group's incentives may outweigh the interests of the majority. The minority is strongly motivated and does not pay any significant price for coordinating the steps taken. The majority is only weakly motivated; due to its numbers and absence of direct personal connections, it pays a rather significant coordination toll. If the costs of coordination for the majority of agents are higher than the losses for each one alone, no majority coalition can emerge. This, in turn, means that the likelihood increases that a decision harmful to the majority will be made.

The success of a project undertaken by an interest group stimulates other groups to attempt to advance their projects. Growth and accumulation of such projects (regulations and redistribution of income) blur the incentives for striving for success. Normally, among interest group members one can find relatively weak entrepreneurs and officials interested in expanding spheres of responsibility and their own authority. ${ }^{51}$

Among factors facilitating the emergence of interest groups (as per the example of the US), Olson makes a special note of urbanization. At the same time, events leading to the undoing of state structures and, accordingly, to the weakening of those interest groups which are associated with them, can at times lower the barriers for

\footnotetext{
${ }^{51}$ Auzan 2002.
} 
economic activity. If the collapsed institutions are replaced by similar ones no worse in quality, a country may make marked progress in economic growth rates, even if it has recently gone through war and defeat, as long as it has at least temporarily rid itself of the parasitism of interest groups. This is precisely how Olson explains the post-WWII achievements of Germany and Japan, and of the Southern States following the Civil War in the US. Olson and his colleagues define the level of interest group impact indirectly, by means of factors favorable or unfavorable to the groups' growth. Thereafter, he conducts a none too complicated statistical test of the mutual connection between average economic growth rates and factors impacting the development of interest groups. Statistical dependence turns out to be negative and significant (the better the conditions for interest groups' growth, the lower the economic growth rates).

The institutions considered above, which belong to the sphere of state regulating of entrepreneurial activity and disclosure of information concerning the functioning of the executive authority offices, share a feature in common. They are all aimed at overcoming the effects (studied in modern institutional theory) of "information asymmetry," which objectively curb the effectiveness of the system of state management and of the political system as a whole.

And indeed, the average voter ("principal") disposes of less information than a deputy of a representative authority office ("agent”). The average deputy ("principal") disposes of less than do government leaders ("agent"), and the government leaders ("principal") have access to less than the leaders of distinct offices ("agent"); the political leadership of the offices ("principal") less than individual officials ("agent"). The upshot of such effects is relatively weak control that the "principal" can exercise over "agents" (voters over deputies, deputies over government, and so on). This prepares the ground for "opportunistic" behavior on the part of "agents," or their acting in their own interest, which violates the interests of the "principal" (including dealings which directly or indirectly involve corruption and simply low-production work).

In the examples considered thus far, three different mechanisms can be singled out, aimed at minimizing the information asymmetry effect: 
Introducing obligatory standards of disclosure of information at the disposal of the authorities and their agencies ${ }^{52}$;

Conducting regular in-depth formal studies (surveys) aimed at testing the effectiveness of regulatory state policy (Regulatory Impact Analysis, RIA), functions of state management offices;

Changes in decision making procedure in executive authority offices, including transition to budget planning targeting results (Performance Budgeting); introducing the institution of formalized testing of regulatory standards ${ }^{53}$ (which raises real accountability of particular agencies to the political leadership in the government, representative authority agencies and voters, as well as handling the use of quantity evaluation of the ratio of costs to benefits (cost-benefit analysis).

In addition, gradually, new mechanisms are beginning to emerge pertaining to public consultations of state authorities directly with the citizens and with public organizations as part of preparing various decisions which can facilitate the democratization of political decision making practices.

The unfolding processes of public computerization and the shaping of electronic government are also political. Foundations are being laid for both limiting corruption $^{54}$ and extending civil involvement in political processes ${ }^{55}$ by means of ensuring appreciably greater transparence of economic, governmental, and legislative processes.

Importing the institutions enumerated above, aimed at combating the effects of information asymmetry, would lay the crucial foundations for growth not only of economic effectiveness of government work, but also of "quality" of the democratic process as a whole (i.e., the importation of these institutions should become the object of political analysis).

\footnotetext{
${ }^{52}$ Freedom of Information and Access to Government Records Around the World, by David Banisar. See http://www.freedominfo.org/survey/

${ }_{53}$ Regulatory Management and Reform. See http://www.oecd.org/EN/home/0,,EN-home-325nodirectorate-no-no-no-2,00.html

${ }^{54}$ V. Thomas et al., The Quality of Growth (Washington, D.C.: World Bank, 2000).

${ }^{55}$ Citizens as Participants: Information, Consultation and Public Participation in Policy-Making (OECD, 2001). See http://www.oecd.org/EN/documents/0,EN-documents-461-nodirectorate-no-15no-11,00.html
} 
Using such indicators as degree of openness or accountability and sensitivity of the government ${ }^{56}$ makes it imperative to pay ever greater attention to questions having to do with reforming the budget system and system of state regulating of entrepreneurship, telecommunications, and level of computerization.

\section{Antitrust}

Comparative studies of "anti-monopoly" processes on the software market ${ }^{57}$ in the US and EU, inter alia, have shown that process outcomes depend less on legislation than on the legal system as a whole, in part even on the competitiveness of the media market. In Russia, even in cases of considerable improvement in the authority ascribed to the courts and in competitiveness of the press, conditions comparable to the US will take shape only in the distant future. Given the present situation, the most effective is gradually to limit the current functions of the antimonopoly management (the Federal Anti-Monopoly Service) to fighting abuse of state offices. A series of functions, such as market monitoring, can be transferred to the Ministry of Economics.

At the same time, it would most likely be helpful to set up an influential office subordinate directly to the government and authorized to permit checkups on businesses, to monitor state violations of honest competition conditions, as well as to coordinate all government proposed law bills after studying the outcome of their impact on business conditions.

It should be noted that the notion of legislation concerning competition, titled "Limiting Market Access" is reasonable and can be defined only in relation to the activities of the state offices themselves and their employees. Many actions forbidden by the Federal Law "Concerning Protecting Competition" are either determined with insufficient exactitude, or not completely connected to competition (for instance, Par. 2 and 5 of Pt. 1, Art. $10^{58}$ ). The very possibility of imprisonment for limiting

\footnotetext{
${ }^{56}$ D. Beetham, "The Idea of Democratic Audit in Comparative Perspective," in: Parliamentary Affairs: A Journal of Comparative Politics, vol. 52 (1999), \# 54.

${ }^{57}$ See D. Cherny, Zaschita konkurentzii na rynkah programmnogo produkta: Uroki opyta SShA $i$ YeS dlya stran s perehodnoy ekonomikoy [Protecting Competition on Software Markets: Lessons of the US and EU Experience] (Moscow: Gaidar Institute for Economic Policy, 2008).

${ }^{58}$ Federal Law "Concerning Protecting Competition" of July 8, 2006, № 135-F3. See http://www.fas.gov.ru/legislative-acts/legislative-acts_9498.html "Elimination of goods from trade if the outcome of such elimination was an increase in the price of the goods": How reliable can proof of a cause-and-effect relationship be? Why should standard petty speculation be persecuted, with elimination of goods in the anticipation of higher prices as a result of higher cost of raw materials, e.g.: "Refusal or avoidance of signing an agreement with certain buyers (clients), unsubstantiated either economically or technically."
} 
competition is under such conditions an "invitation" to abuse power. It must be done away with. In Russia's case, this means eliminating from Art. 178 of the RF Criminal Code any mention of penalties involving loss of freedom.

\section{Over-Protection of Rights and Privileged Sectors}

Special attention paid by the state to certain sectors of the economy and disproportionate protection of certain property rights violate the rights of both consumers and partners, as well as lower inter-branch competition for capital and work force.

This is why general approaches to property protection and, correspondingly, penalties for rights violations should be universal. They should exclude the possibility of diversifying the severity of the penalties for appropriating the same amount of money in different branches of business; the same goes for the possibility of selective punishment in cases when for technical reasons, the protective law cannot be applied universally.

Similarly, it will be helpful gradually to enable legal systems to rule out punishments involving loss of freedom for property legal violations. At the same time, options of taking refuge in comfortable modern legal norms for bankruptcy should be made more restrictive, insofar as that from a moral point of view, given such an option, the difference between stealing and refusing to pay a debt is negligible. From an economic point of view, greater chances of avoiding punishment encourage dishonest individuals to switch from common stealing to dishonest business.

Perfecting and developing systems of non-state arbitration and self-defense in this area seems a promising direction.

\section{Presuming the Market Agent Is Endowed with Common Sense}

The assumption made by lawyers and officials that a person legally defined as capable of concerted action and normal functioning, also possesses common sense and the ability to make responsible choices is rooted in the history of common law (US, Great Britain ${ }^{59}$ ).

Assuming that an economic agent is capable of reasonable and concerted action leads to much smaller risks of state over-regulating of business than does the opposite

\footnotetext{
${ }^{59}$ The strong negative correlation between the tradition of common sense and that of increasing state control is discussed at length by, inter alia, the well-known American lawyer P. Howard (Howard 2001, 1994).
} 
kind of assumption. Many of the problems faced by the reasonable consumer may be solved by specifying a universal approach to the consumer's right to information. That is, a legislated (and legally enforced) way is called for which would perfect a universal package of requirements obligatory for business to meet by duly informing clients (about the cost of a purchase, meaning the price really paid, rather than the minimal cost for the particular type of good in question, or the price prior to the payment of some tax, and so on; about conditions and requirements for use and other technical and legal conditions for purchasing a good or a service), similar to legal standards already in effect which pertain to information disclosure in open shareholding societies.

The state's admitting (by means of enacted laws) that market agents are possessed of common sense will in the future simplify the task of curbing excess authorization of officials. Such a refusal will also make it possible to "privatize" a series of state functions in favor of NGOs, primarily consumer rights defense organizations. Thus, a wisely chosen balance of rights and responsibilities to be assumed by sellers and buyers in common law and laws concerning consumer rights will facilitate destroying the legal basis for most attempts aimed at introducing new business regulations.

\section{Licensing and Self-Regulating}

It is important to note that the simple fact of the state's refusal directly to interfere while maintaining measures such as compulsory insurance and compulsory certification for self-regulating organizations (created under government pressure, and often subject to government control), does not guarantee improvement of the situation. There is a risk that as the decision making chain grows and the number of mediators and barriers separating producers from market agents increases, all the same problems will be retained. ${ }^{60}$

The "organized public" of self-regulating organizations can be more forceful in neutralizing incentives for decision makers than a common bureaucratic structure. This latter is compelled to respond to external (political) pressure, especially when political and media competition is in evidence. In the case of pseudo-private selfregulating, all the negative moments resulting from state bulkiness and lack of interest in the final outcome will remain.

\footnotetext{
${ }^{60}$ See project materials for "Study of Real Barriers and Sources of Political and Legal Risks for Business in Russia" (2009) on "Lowering Quality" of corruption (World Bank).
} 
Only in case the system of state licensing leaves room for the certification system thus taking shape and for a genuine, not state-dictated self-regulating, can lower business costs be expected.

\section{Commensurability of Crime and Punishment}

Quite an important component of reform is a unified system of penalties for attempts to infringe upon property rights.

On the one hand, it is helpful to encourage self-defense of rights, private landed estates, and other property. Given such an endorsing approach, self-defense develops into activity by unions of property owners who cooperate in jointly bearing the costs of standard court methods of defense.

On the other hand, penalties imposed by the state must be commensurate with the crimes. In cases of crimes against property which do not involve violence, resorting to prison terms ${ }^{61}$ seems an a priori exaggerated punishment. Property responsibility with due compensation should be in force, along with considerable restrictions to be imposed on opportunities for citizens found guilty based on due process of law.

It is precisely with regard to violations involving neither violence nor threat of violence that the arguments put forth by opponents of severe penalties seem particularly apt. It is no accident that most instances cited to illustrate the injustice of medieval systems of punishment belong to the category of punishments for petty theft. ${ }^{62}$

Otherwise, the effectiveness of the law as incentive regulator is undermined, if causing the loss of human life is punished in a way similar to petty theft. ${ }^{63}$ This brings us back into the Middle Ages, when capital punishment was imposed equally for either stealing a chicken or committing murder.

It is important to stress that all the measures enumerated presuppose the preliminary construction of an independent court system: first a general state system of jurisdiction and following that, specialized court networks, including private arbitration. The ability of such a system to resolve disputes involving private persons or state offices with minimal rights violations will make it possible to prevent the

\footnotetext{
${ }^{61}$ Limiting freedom by means of compulsory (forced) labor - such as for debtors not having the means to repay their loans and unable to find employment on their won - is not what is meant in this case.

${ }^{62}$ See, for instance, Romanov 2000, p. 89.

${ }^{63}$ For consequences for incentives, see Becker 2000.
} 
proliferation of legal enactments and practices which impose inflated extra-tax burdens on private business and the consumers of its goods and services.

\section{Bibliography}

Amalrik A. Notes of a Revolutionary. Knopf, 1982.

Annual Report of the Chief Counsel for Advocacy on Implementation of the Regulatory Flexibility Act Report for fiscal year 2001.

Armentano Dominick T. Antitrust The Case for Repeal Revised 2nd Edition MISES

Becker G.S. Public Policies, Pressure Groups, and Dead Weight Costs // Journal of Public Economics. 1985. N 28.

Becker Gary S. "Crime and Punishment: An Economic Approach" // Journal of Political Economy 76, no. 2 (March/April 1968): 169-217

Beetham D. The Idea of Democratic Audit in Comparative Perspective // Parlamentary Affairs. A Journal of Comparative Politics. 1999. Vol. 52. № 54.

Coase R "The Firm, the Market and the Law" University of Chicago Press, 1990 de Soto Hernando The Mystery of Capital: Why Capitalism Triumphs in the West and Fails Everywhere Else Basic Books; 1st edition, 2003

de Soto Jesús Huerta "Money, Bank credit, and economic cycles" $2^{\text {nd }}$ edition Ludwig von Mises Institute Auburn, Alabama http://mises.org/books/desoto.pdf

Frye T. Markets, Democracy and New Private Business in Russia. Ohio State University, 2002.

George J.S. The Theory of Economic Regulation // Bell Journal of Economics and Management Science 2. Spring 1971. N 1. P. 1-21.

Hahn R., Hird J. The Costs and Benefits of Regulation: Review and Synthesis // Yale Journal on Regulation. Vol. 8. N 1. Winter 1991.

Hernando De Soto, The Other Path: The Invisible Revolution in the Third World, Harper Collins, 1989

Hill, Jefferson B. Government Capacities to Assure High Quality Regulation report for Regulatory Management and Reforms OECD Seminar Moscow November 19-20

2001, Moscow http://www.oecd.org/gov/regulatory-policy/2724531.pdf

Howard O. Working on Legal Culture Changes in Kyrgyzstan: Drafting Practical Commentaries on Civil Code. IRIS, 1996.

Howard P.K. The Lost Art of Drawing the Line: How Fairness Went Too Far. N.Y.: Random House, 2001; Idem. The Death of Common Sense: How Law Is Suffocating America. N.Y.: Random House, 1994.

Kahneman D., Slovic P., Tversky A. (eds.) Judgment under uncertainty: Heuristics and biases. N.Y.: Cambridge University Press, 1982.

Kaufmann D., Kraay A., Mastruzzi M. Governance Matters VI. Aggregate and individual governance indicators 1996-2006. World Bank publications // Working Papers. wps4280, 2007.

Kirzner Israel M. "Competition and Entrepreneurship" University Of Chicago Press, 1978

Ladegaard P., "Good Governance And Regulatory Management" Regulatory

Management and Reforms OECD Seminar Moscow November 19-20 2001, Moscow

http://www.oecd.org/gov/regulatory-policy/2724495.pdf

Ludwig von Mises Institute Auburn, Ala. 36832-4528 www.mises.org 
Mau V., Yanovskiy K. «Political and Legal Factors of Economic Growth in Russian Regions" "Post-Communist Studies", Vol.14, No. 3, 2002

Mulder N. Canadian Experience with Railway Deregulation in Canada. CEPRA Memorandum, April 2000. http://www.aucc.ca/en/programs/cepra/cepraprogram.html\#Publications

OECD Recommendation of the Council of the OECD on Improving the Quality of Government Regulation, 1995.

OECD Report on Regulatory Reform. Vol. I: Sectoral Studies. Paris, 1997.

OECD Reviews of regulatory reform: Russia. Building rules for Market. OECD, 2005.

Office of Management and Budget Office of Information and Regulatory Affairs. Making Sense of Regulation 2001. Report to Congress on the Costs and Benefits of Regulations and Unfunded Mandates on State, Local, and Tribal Entities. 2001.

Office of Management and Budget, Executive Office of the President of the United States Report to Congress On the Costs and Benefits of Federal Regulations. Washington, 2001.

Olson M. Power and Prosperity. N.Y.: Basic Books, 2000.

Olson M. The Rise and decline of nations. Yale University Press, 1982.

Olson M., Sarna S. Governance and Growth: A Simple Hypothesis Explaining CrossCountry Differences in Productivity Growth. IRIS, 1998.

Olson, Mancur [1965]. The Logic of Collective Action : Public Goods and the Theory of Groups (Revised edition ed.). Harvard University Press, 1971

President of the United States Executive Order 12866 - Regulatory Planning and Review. October $4 . \quad 1993$ http://www.gao.gov/special.pubs/regulatory_review/eo_12866.pdf .

Priorities for the President // Edited by Stuart M. Butler and Kim R. Holmes. The Heritage Foundation. Washington DC, 2001.

Robert S.S. Some Basic Ways Good Law, Good Legal Institutions, and Sound Principles of the Rule of Law Can Help Augment Markets. IRIS, 1999.

S. Zhavoronkov, V. Mau, D. Chernyi, K. Yanovskiy, 2002. "The Deregulation of the Russian Economy," Problems of Economic Transition, M.E. Sharpe, Inc., vol. 45(5), pages 5-66, September.

Sleifer A., Vishny R. Corruption // Quarterly Journal of Economics. Vol. 108. N 3. August 1993.

Slivinski S. The Corporate Welfare State. How Federal Government subsidizes US Businesses. Cato Institute Policy analysis \# 592, May 14. 2007.

Stigler G.J. (1970), Director's Law of Public Income Redistribution, Journal of Law and Economics 13: 1-10.

Swain H. Canadian Experience with Deregulation. CEPRA Memorandum April 2000. http://www.aucc.ca/en/programs/cepra/cepra-program.html\#Publications

The International Union, United Automobile, Aerospace and Agricultural Implement Workers of America (UAW), web site www.uaw.org.

Vickers $J$. The state regulation policy // Oxford review of economic policy. Vol. 7. Article 3, 1993. Oxford college of economics and statistics.

Wallace M. On the Prospects of Legal Reform in the Kyrgyz Republic. IRIS, 1996. Weidenbaum M. Regulatory Process Reform from Ford to Clinton Regulation // Vol. 20.

N 1.1997. 
World Bank A Better Investment Climate for Everyone annual World Development Report for 2005 http://siteresources.worldbank.org/INTWDRS/Resources/477365$1327693758977 /$ complete_report.pdf

Yingyi $Q$. The Institutional Foundations of China's Market Transition. www.worldbank.org/.../swp99011.pdf

Zamulin O. Small Businesses Harassed in Russia Despite New Deregulation Results of a Business Survey http://www.worldbank.org/html/prddr/trans/julaugsep02/pgs44-45.htm. World Bank, 2002.

\section{Sources available in Russian only}

Novikov V. "Antimonopolnoe regulirovanie I etika effectivnosty" (Antimonopoly $\begin{array}{llll}\text { regulation and ethics of } & 2004 .\end{array}$ http://www.libertarium.ru/libertarium/151381.

Novikov V., Luzan S. "Tsely antimonopolnyh zakonov v Rossii I v drugih stranah mira" (Goals of antimonopoly legislation in Russia and abroad). Moscow, 2003. http://www.prompolit.ru/148350.

Mau Vladimir, S. Zhavoronkov, A.Shadrin K.Yanovskiy "Deregulirovanie rossiyskoy ekonomiki: Mekhanizm vosproizvodstva izbytochnogo regulirovaniya i institutzional'naya podderzhka konkurentzii na tovarnyh rynkah" (Deregulation of the Russian Economy: Mechanism for Reproducing Excess Regulatory Control and Institutional Support for Competition on the Goods Markets] (Moscow: IEP, 2003); see $\quad$ http://www.iet.ru/papers/48/index.htm .

Moscow, IET 2003

Mau V., Boreskova Ye., Novikov V. "Problemy ustoychivosty ekonomichesko" Problem of economic legislations' sustainability Moscow, IET, 1999 http://www.iep.ru/ru/problema-ustoichivosti-ekonomicheskogo-zakonodatelstva3.html

Auzan A.(ed.) "Administrativnye bar'ery $\mathrm{v}$ ekonomike: institucionalny analiz" (Administrative barriers in economy: institutional analysis). Moscow NGO "Social Contract"; .: ИИФ «Спрос» КонфОП, ИНП «Общественный договор», 2002.

Romanov A.K. " The Legal System of England" Moscow, Delo, 2000

Tambovcev V.L. Economic theory of compliance and enforcement of the Government // Voprosy Ekonomiky (Problems in Economics) . 2004. \# 4.

M. Mokhtari, S. Caner, V.Kontorovich "An Econometric Analysis of the non-payments

Problem in the Russian Federation" HSE Economic Journal Vol 4 \#1 2000 pp. 3-16 http://uisrussia.msu.ru/docs/nov/hse_ejournal/2000/1/04_01_03.pdf

Klyamkin I, Timofeev L. "Shadow Russia" Moscow, Russian Humanitarian University, 2000

Kulisher I.M. History of Economic Life in Western Europe. Chelyabinsk: Socium Publishing House, 2004.

Kuznetzov P.V., Luzan S.A., Stasyuk K.V., et al.. "Enterprises with Government owned shares. Institutional and legal aspects and economic efficiency" Moscow Public Scientific Fund, Moscow, 2004. «Scientific Reports» series \#155. http://www.mpsf.org/lib.html

Kayuchenko V.V. Social Audit as an instrument for analytical and informational component of strategic Programs: Theses for Scientific Degree of Candidate in Economics (manuscript) Moscow, 2010. 